\title{
PERANCANGAN PENERAPAN METODE 5S DI PABRIK SARINDA BAKERY
}

\author{
N. E. Maitimu \\ Program Studi Teknik Industri, Fakultas Teknik Universitas Pattimura, Ambon \\ Helga. Y. P. Ralahalu \\ Program Studi Teknik Industri, Fakultas Teknik Universitas Pattimura, Ambon
}

\begin{abstract}
ABSTRAK
Metode 5S (Seiri, Seiso, Seiton, Seiketsu dan Shitsuke) merupakan metode penyempurnaan tempat kerja yang dilakukan secara berkelanjutan untuk menjadi kondisi yang lebih baik.Sasaran $5 S$ adalah peningkatan jumlah produksi dengan menghilangkan pemborosan (waste) selama proses produksi.Pemborosan-pemborosan tersebut harus dikurangi karena menimbulkan biaya-biaya yang menyebabkan berkurangnya untung suatu perusahaan.Penelitian ini merancang penerapan meotde $5 S$ di Sarinda Bakery untuk menjamin ruang produksi bersih dan sehat, serta menata ruang tersebut agar memenuhi standar yang telah ditentukan.
\end{abstract}

Kata Kunci:5S, Produktivitas Kerja, Peningkatan Produksi

\begin{abstract}
The 5S method (Seiri, Seiso, Seiton, Seiketsu, and Shitsuke) is a method of improving the workplace sustainably to be a better condition. The goal is to improve the production number by eliminating waste during its process. Those wastes result in costs that reduce business profit. This study is arranged to design and implementation of the $5 S$ method in Sarinda Bakery. It aims to guaranty the cleanliness and health of their production room and to manage it according to the standards.

Keywords:5S Method, Work Productivity, Increased Production.
\end{abstract}

\section{PENDAHULUAN}

Perkembangan industry di Indonesia sangat pesat, hal ini dapat dilihat dengan banyaknya perusahaan bergerak di bidang manufaktur, mulai dari perusahaan skala kecil sampai skala besar. Perkembangan industry yang sangat pesat, ini juga terjadi pada industry roti yang memiliki pasar lokal sampai nasional. Industry roti harus dapat meningkatkan daya saing dan keunggulan dalam semua sektor seperti mempersiapkan sumber daya manusia yang tangguh dan berkualitas sehingga dapat menghasilkan produk yang sehat dan berkualitas sesuai dengan keinginan pelanggan. Salah satu faktor untuk mencapai hal tersebut adalah kegiatan proses produksi. Pada prinsipnya kegiatan proses produksi memiliki peranan yang sangat penting bagi perusahaan, semakin baik berlangsungnya proses produksi maka akan semakin baik pula dampaknya bagi perusahaan.

Kegiatan produksi dipengaruhi oleh budaya kerja. Budaya kerja adalah suatu sifat kebiasaan dalam suatu kelompok tercermin dalam sikap menjadi perilaku tindakan yang terwujud sebagai kerja. Budaya kerja yang diterapkan untuk memperbaiki kualitas lingkungan kerja adalah budaya kerja 5S (Seiri, Seiton, Seiso, Seiketsu, Shitsuke). Budaya kerja 5S tidak hanya baik digunakan untuk memperbaiki kualitas lingkungan kerja, tapi juga dapat memperbaiki cara berpikir karyawan terhadap pekerjaannnya (Viviyanti, 2008).

Sarinda Bakery adalah suatu pabrik roti yang mulai beroperasi pada tahun 1977 di J1 Rijali no. 7 Ambon. Dan merupakan pabrik roti pertama yang berproduksi secara massal di kota Ambon, dengan memiliki empat divisi. Roti-roti Sarinda dengan motto "Open Fresh \& Tasty" ini dipasarkan di hampir seluruh outlet-outlet seperti supermarket, minimarket, toko, warung dan lain-lain di kota Ambon, kemudian pemasarannya meluas ke pulau Ambon, dan sekarang sudah menjangkau ke pulau-pulau di sekitarnya. 
Dilihat dari pabrik Sarinda yang memproduksi makanan berupa roti, dengan berbagai varian rasa, maka sudah tentunya keadaan pabrik khususnya pada ruang produksi harus di jamin kebersihan dan kesehatannya, serta penataan pada ruang tersebut harus memenuhi standar yang telah di tentukan.

Pada saat ini Pabrik Sarinda belum sepenuhnya menerapkan budaya kerja 5S. secara umum umum keadaan pabrik yang belum tertata dengan rapi, belum adanya pembagian peralatan sesuai fungsinya, dan belum memiliki petunjuk jalan. Permasalahan ini akan mengganggu proses produksi, transportasi dan kinerja operator.

Keadaan ini mengakibatkan operator atau para pekerja merasa cepat jenuh, dan tidak nyaman serta membingungkan. Hal ini tentulah bukan merupakan tindakan yang efisien, Dengan demikian Salah satu upaya pendekatan yang dapat di lakukan untuk memperbaiki lingkungan kerja adalah dengan budaya kerja 5S. Tujuan dari pada penelitian ini adalah untuk mendapatkan kondisi kerja yang lebih baik dan memberikan usulan perbaikan kondisi kerja di pabrik Sarinda dengan melakukan perancangan penerapan $5 S$.

\section{LANDASAN TEORI}

\section{Pengertian 5S}

Program 5S berasal dari Jepang dan telah berhasil membawa industri Jepang dikagumi di seluruh dunia. Realitas ini menjadi perhatian besar sehingga program ini kemudian diadopsi oleh berbaga industri di berbagai negara. Jika anda memasuki sebagian besar perusahaan manufaktur yang berada di luar Jepang pada tahun 1980-an. 5S merupakan sebuah alat untuk membantu mengungkapkan masalah dan bila digunakan secara canggih, dapat menjadi bagian dari proses pengendalian visual dari sebuah sistem lean yang direncanakan dengan baik (Devani, 2016).

Konsep 5S merupakan metode penyempurnaan tempat kerja yang dilakukan secara berkelanjutan untuk menjadi kondisi yang lebih baik dari kondisi sebelumnya, sasaran terakhir 5S adalah peneingkatan produksi. Penerapan 5S dalam dunia usaha adalah berusaha menghilangkan pemborosan (waste). Pemborosan-pemborosan tersebut harus dikurangi karena menimbulkan biaya-biaya yang menyebabkan berkurangnya untung suatu perusahaan (RInawati dan Lisano, 2016), 5S merupakan konsep yang sangat sederhana sehingga mudah dimengerti baik tujuan maupun penerapannya. Namun, 5S ini sulit sekali diterapkan dengan benar. banyak orang beranggapan bahwa sikap kerja yang produktif dan tempat kerja yang tertata rapi ada dengan sendirinya, tetapi kenyataannya menunjukan bahwa hal itu masih harus diciptakan. Masih banyak orang yang menganggap bahwa 5S identik dengan kebersihan, sesuatu anggapan yang tidak sepenuhnya salah dan juga tidak sepenuhnya benar. Tetapi bisa dilihat dan membaca melalui buku-buku atau literatur yang lain bahwa pada dasarnya 5S merubah Basic Mentality kita dan melakukan perubahan dari suatu hal-hal yang sederhana yang bisa kita lakukan saat ini juga.

1. Seiri (Ringkas/Pemilahan)

Seiri Merupakan kegiatan penyusunan, dalam arti memilah semua peralatan, bahan, dan lain-lain di tempat kerja dan memastikan bahwa barang yang diperlukan disimpan dalam jangkauan supaya lebih efisien dengan memperhatikan frekuensi pemakaian. Benda lainnya dapat disimpan atau dibuang jika tidak perlu. Hal ini dapat mengurangi ketidakefektifan dalam bekerja (Halim, 2006). Imai (1997) menyatakan seiri merupakan kegiatan pengklasifikasian barang mana yang diperlukan dan tidak diperlukan di tempat kerja.

Menurut Takashi Osada Seiri adalah mengatur segala sesuatu, memilah sesuai dengan aturan atau prinsip tertentu. Seiri berarti membedakan antara yang diperlukan dengan yang tidak diperlukan, mengambil keputusan yang tegas, dan menerapkan manajemen stratifikasi untuk membuang yang tidak diperlukan. lebih menitik beratkan kepada manajemen stratifikasi dan mencari penyebab-penyebabnya untuk menghilangkan yang tidak diperlukan tanpa menimbulkan masalah.

2. Seiton (Rapi/Penataan)

Seiton/Rapi berarti menyimpan barang di tempat yang tepat atau dalam tata letak yang benar sehingga dapat dipergunakan dalam keadaan mendadak. Hal itu merupakan cara untuk menghilangkan pencarian (Wiratmani, E, 2015). Menurut Takashi Osada Seiton sebagai suatu kegiatan menyimpan barang di tempat yang tepat atau dalam tata letak yang benar sehingga dapat dipergunakan dalam keadaan mendadak. Hal ini merupakan cara untuk menghilangkan proses pencarian.

3. Seiso (Resik/Pembersihan)

Seiso/Resik berarti membersihkan barang sehingga menjadi bersih. Dalam hal ini berarti membuang sampah, kotoran dan benda asing serta membersihakan segala sesuatu. Diutamakan sebagai pemeriksaan terhadap kebersihan dan menciptakan tempat kerja yang tidak memiliki cacat dan cela (Waluyo, 2011). 
Seiso berarti membersihkan barang-barang sehingga menjadi bersih, membuang sampah, kotoran dan benda-benda asing serta membersihkan segala sesuatu.

4. Seiketsu (Rawat)

Seiketsu/Rawat berarti terus-menerus dan secara berulang-ulang memelihara Ringkas, Rapi, dan Resik. Dengan demikian Rawat mencakup kebersihan pribadi dan lingkungan (Waluyo, 2011). Seiketsu sebagai pemantapan yang dilakukan secara terus-menerus dan berulang-ulang memelihara pemilahan, penataan dan pembersihannya.

5. Shitsuke (Rajin/Pembiasan)

Shitsuke/Rajin berarti pelatihan dan penigkatan kemampuan untuk melakukan apa yang ingin kita lakukan meskipun hal tersebut sulit untuk dilakukan (Yunita, 2007). Shitsuke berarti suatu pelatihan dan kemampuan untuk melakukan apa yang ingin dilakukan meskipun itu sulit dilakukan. Dalam istilah shitsuke, ini berarti menanamkan (atau memiliki) kemampuan untuk melakukan sesuatudengan cara yang benar (Osada, 2004). Dalam hal ini penekanannya adalah untuk menciptakan tempat kerja dengan kebiasaan dan perilaku yang baik. Dengan mengajarkan setiap orang apa yang harus dilakukan dan memerintahkan setiap orang untuk melaksanakannya, maka kebiasaan buruk akan terbuang dan kebiasaan baik akan terbentuk.

\section{Skala Kuesioner}

"Skala Likert adalah skala yang digunakan untuk mengukur persepsi, sikap atau pendapat seseorang atau kelompok mengenai sebuah peristiwa atau fenomena sosial, berdasarkan definisi operasional yang telah ditetapkan oleh peneliti".

Suatu skala psikometrik yang umum digunakan dalam kuesioner, dan merupakan skala yang paling banyak digunakan dalam riset berupa survei. Penggunaan yang penelitian yang sering menggunakan skala ini adalah bila penelitian menggunakan jenis penelitian Survei Deskriptif (Gambaran). Nama skala ini diambil dari nama penciptanya Rensis Likert, yang menerbitkan suatu laporan yang menjelaskan penggunaannya. Sewaktu menanggapi pertanyaan dalam skala Likert, responden menentukan tingkat persetujuan mereka terhadap suatu pernyataan dengan memilih salah satu dari pilihan yang tersedia.

Peneliti mengumpulkan item-item yang cukup banyak, relevant dengan masalah yang sedang diteliti, dan terdiri dari item yang cukup jelas disukai dan tidak disukai. Kemudian item-item itu dicoba kepada sekelompok responden yang cukup representatif dari populasi yang ingin diteliti. Responden di atas diminta untuk mengecek tiap item, apakah ia menyenangi (+) atau tidak menyukainya (-). Respons tersebut dikumpulkan dan jawaban yang memberikan indikasi menyenangi diberi skor tertinggi. Tidak ada masalah untuk memberikan angka 5 untuk yang tertinggi dan skor 1 untuk yang terendah atau sebaliknya. Yang penting adalah konsistensi dari arah sikap yang diperlihatkan. Demikian juga apakah jawaban "setuju" atau "tidak setuju" disebut yang disenangi, tergantung dari isi pertanyaan dan isi dari item-item yang disusun.

Total skor dari masing-masing individu adalah penjumlahan dari skor masing-masing item dari individu tersebut. Respon dianalisis untuk mengetahui item-item mana yang sangat nyata batasan antara skor tinggi dan skor rendah dalam skala total. Misalnya, responden pada upper $25 \%$ dan lower $25 \%$ dianalisis untuk melihat sampai berapa jauh tiap item dalam kelompok ini berbeda. Item-item yang tidak menunjukkan beda yang nyata, apakah masuk dalam skortinggi atau rendah juga dibuang untuk mempertahankan konsistensi internal dari pertanyaan.

Dalam menyusun skala, item-item yang tidak jelas menunjukkan hubungan dengan sikap yang sedang diteliti masih dapat dimasukkan ke dalam skala. Dalam menyusun skala Thurstone, yang dimasukkan hanya item-item yang telah disetujui bersama dan jelas berhubungan dengan sikap yang ingin diteliti saja yang dapat dimasukkan. Skala Likert lebih mudah membuatnya dibanding skala Thurstone. Skala Likert mempunyai reliabilitas yang relatif tinggi dibandingkan dengan skala Thurstone untuk jumlah item yang sama.

Makin banyak jumlah item, maka makin kurang reliabilitasnya. Skala Likert dapat memperlihatkan item yang dinyatakan dalam beberapa respons alternatif ( $S S=$ sangat setuju, $S=$ setuju, $R=$ ragu-ragu, TS=tidak setuju, STS=sangat tidak setuju). Sedangkan skala Thurstone hanya membuka dua alternatif saja.

\section{Uji Validitas}

Menurut Sekaran, uji validitas bertujuan untuk mengukur valid tidaknya suatu item pernyataan. Uji ini pada SPSS 20 dapat dilihat dalam kolom Corrected Item-Total Correlation yag merupakan $r$ hitung untuk masing-masing pernyataan. Jika $r$ hitung lebih besar dibandingkan dengan $r$ tabel maka butir pernyataan tersebut dapat diterima atau valid. Sebelum mencari $r$ tabel dalam tabel statistic $r$, peneliti 
terlebih dahulu harus menentukan berapa derajat kebebsannya. Adapun rumus derajat kebebsan (degree of freedom) adalah jumlah responden dikurangi $2(\mathrm{df}=\mathrm{n}-2)$.

\section{Uji Realibilitas}

Pengujian reliabilitas dilakukan untuk mendapatkan jawaban yang konsisten atau stabil dari waktu ke waktu. pengujian ini dilakukan dengan menggunakan program SPSS versi 20 dimana dalam mengukur reliabilitas disini menggunakan uji statistic Cronbach Alpha ( $\alpha$ ), yang mana suatu variable dikatakan reliable jika memiliki Cronbach Alpha lebih dari 0,06 ( >0,06). Hasil pengujian uji reliabilitas instrument menggunakan alat bantu oleh statistic SPSS versi 20 for windows.

\section{METODE PENELITIAN}

Variabel dan Definisi Operasional

Yang termasuk dalam indikator variabel keputusan dalam penilitian adalah sebagai berikut : Pemilahan, Perawatan, Peralatan

Variabel keputusan merupakan suatu indikator untuk mencapai variabel tujuan. Yang mana variabel tujuan adalah Produktivitas Kerja pada Sarinda Bakery.

\section{Metode Analisa Data}

Metode dalam penelitian ini dengan menggunakan metode 5S untuk mendapatkan kondisi kerja yang lebih baik dan memberikan usulan perbaikan kondisi kerja di pabrik Sarinda dengan melakukan perancangan penerapan $5 \mathrm{~S}$.

Berikut ini merupakan flowchart dari penelitian ini.

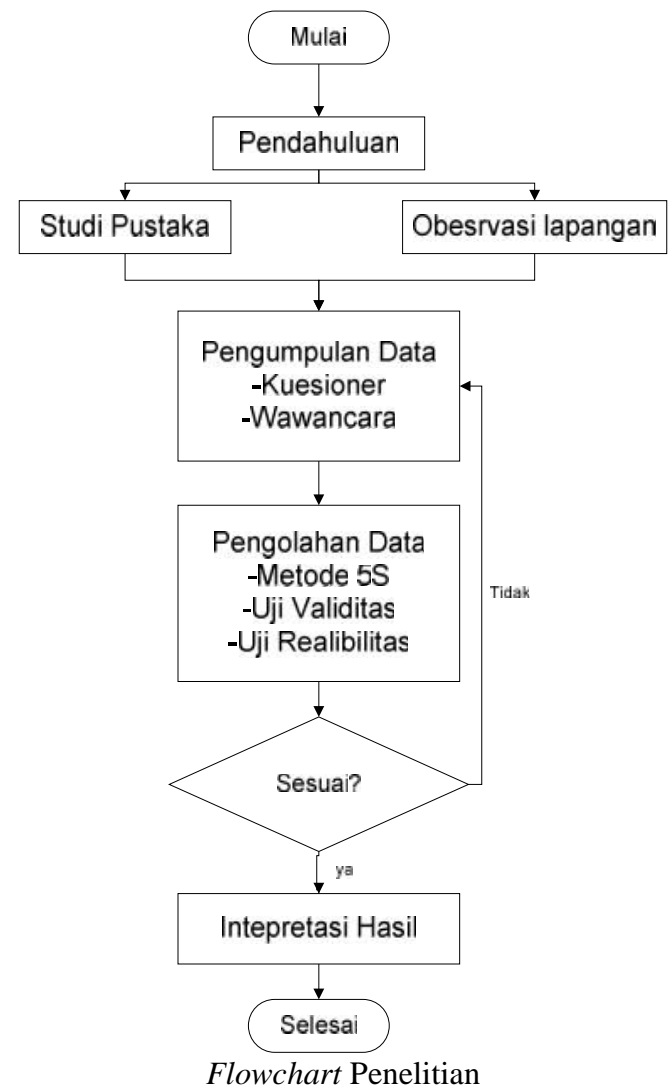

\section{HASIL DAN PEMBAHASAN}

Jumlah Karyawan Pada Pabrik Sarinda Bakery

Pabrik Sarinda bakery memiliki 5 divisi yakni divisi produksi, penjualan (internal dan external), servis \& maintenance dan finance. Dengan memilki 4 pekerja, yang masing- masing 28 orang pekerja laki-laki dan 26 orang pekerja perempuan, yang memilki 6 hari kerja dan 7 jam kerja dalam sehari. Berikut ini adalah tabel jumlah pekerja pada Pabrik sarinda bakery. 
Jumlah Karyawan Masing-masing Divisi Pada Pabrik Sarinda Bakery

\begin{tabular}{|l|c|c|c|c|c|c|}
\hline & \multicolumn{7}{|c|}{ DIVISI } & \multirow{2}{*}{ Jumiah } \\
\hline & Produksi & Sales (In) & $\begin{array}{c}\text { Sales } \\
\text { (Ex) }\end{array}$ & $\begin{array}{c}\text { Servis \& } \\
\text { Maintenance }\end{array}$ & Finance & \\
\hline Laki-laki & & 24 & 1 & 2 & 1 & 28 \\
\hline Perempuan & 24 & 2 & & & & 26 \\
\hline \multicolumn{7}{|c|}{ To tal } \\
\hline
\end{tabular}

\section{Proses Produksi Roti Pada Pabrik Sarinda Bakery}

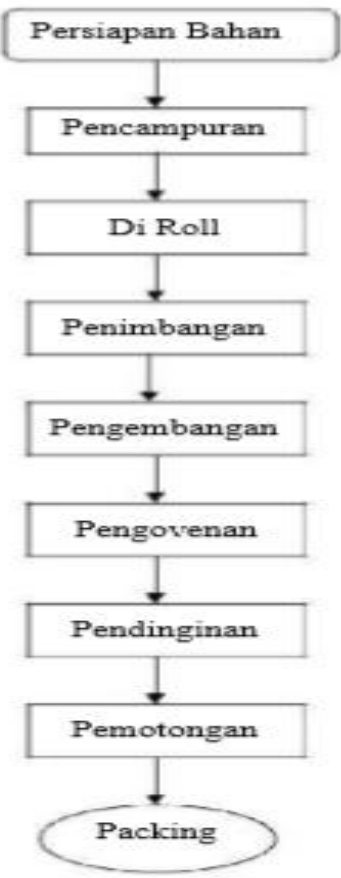

Proses pembuatan roti sarinda

Diagram Alir Pembuatan Roti

1. Persiapan bahan-bahan untuk proses pembuatan roti

2. Bahan-bahan yag telah disiapkan dicampur menjadi satu ke dalam mixer. Kemudian di campur sampai kalis (merata).

3. Adonan yang telah dicampur kemudian diangkat dan di roll biar lebih halus

4. Setelah di roll sampai halus, adonan ditimbang sesuai dengan jenis roti.

5. Setelah itu, adonan dimasukan kedalam kamar uap untuk pengembangan.

6. Setelah proses pengembangan adonan dimasukan kedalam oven hingga matang

7. Setelah dilekuarkan dari oven kemudian didinginkan. Setelah itu dipotong selanjutnya dioles mentega dan kemudian di bungkus (packing) dan dijual
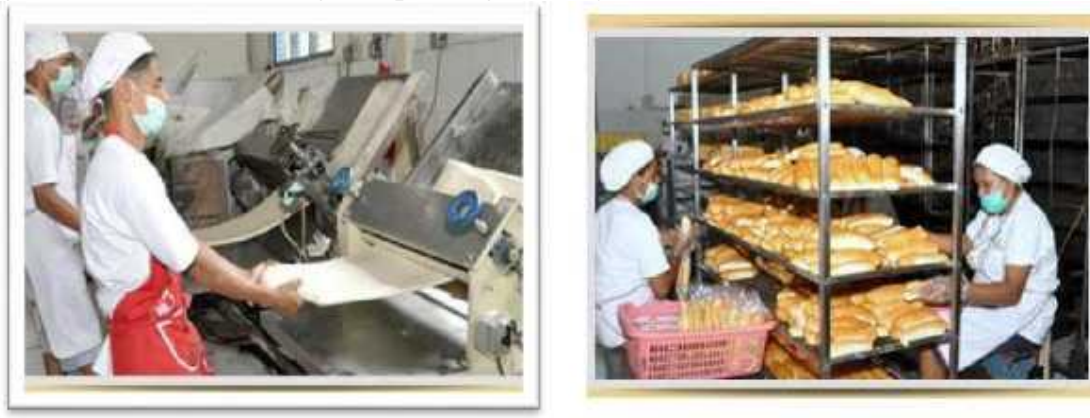

Proses Produksi Roti Sarinda 
Rekapitulasi Kuesioner (5S)

\begin{tabular}{|c|c|c|c|c|c|c|c|c|c|c|}
\hline No & \multicolumn{10}{|c|}{ S A M P E / RESPONDEN } \\
\hline & P1 & P2 & P3 & P4 & P5 & P6 & P7 & P8 & P9 & P10 \\
\hline 1 & 2 & 3 & 1 & 1 & 3 & 3 & 2 & 3 & 1 & 2 \\
\hline 2 & 4 & 4 & 5 & 5 & 5 & 5 & 5 & 4 & 5 & 4 \\
\hline 3 & 1 & 2 & 1 & 2 & 2 & 1 & 1 & 1 & 1 & 1 \\
\hline 4 & 2 & 2 & 2 & 2 & 3 & 1 & 1 & 2 & 2 & 2 \\
\hline 5 & 2 & 4 & 3 & 4 & 3 & 3 & 5 & 4 & 3 & 4 \\
\hline 6 & 4 & 5 & 4 & 5 & 5 & 4 & 5 & 5 & 5 & 5 \\
\hline 7 & 2 & 3 & 1 & 3 & 3 & 3 & 1 & 2 & 1 & 2 \\
\hline 8 & 2 & 3 & 2 & 4 & 4 & 2 & 2 & 4 & 2 & 2 \\
\hline 9 & 2 & 3 & 1 & 2 & 4 & 3 & 1 & 2 & 1 & 2 \\
\hline 10 & 2 & 2 & 2 & 2 & 3 & 1 & 1 & 1 & 2 & 1 \\
\hline 11 & 2 & 1 & 2 & 2 & 3 & 3 & 1 & 2 & 2 & 2 \\
\hline 12 & 3 & 3 & 3 & 4 & 4 & 4 & 4 & 4 & 3 & 4 \\
\hline 13 & 2 & 2 & 1 & 3 & 2 & 2 & 2 & 2 & 1 & 1 \\
\hline 14 & 3 & 1 & 1 & 1 & 3 & 2 & 1 & 2 & 1 & 2 \\
\hline 15 & 2 & 3 & 1 & 2 & 3 & 4 & 3 & 3 & 1 & 1 \\
\hline 16 & 4 & 4 & 5 & 4 & 3 & 4 & 3 & 4 & 5 & 5 \\
\hline 17 & 4 & 5 & 4 & 5 & 4 & 5 & 5 & 5 & 4 & 4 \\
\hline 18 & 3 & 5 & 4 & 5 & 5 & 3 & 4 & 3 & 5 & 4 \\
\hline 19 & 2 & 4 & 2 & 5 & 5 & 4 & 5 & 1 & 2 & 2 \\
\hline 20 & 2 & 2 & 1 & 2 & 2 & 2 & 1 & 2 & 1 & 2 \\
\hline 21 & 2 & 2 & 2 & 2 & 2 & 2 & 1 & 1 & 2 & 2 \\
\hline 22 & 4 & 5 & 5 & 4 & 5 & 5 & 5 & 4 & 5 & 5 \\
\hline 23 & 1 & 4 & 1 & 1 & 3 & 4 & 1 & 3 & 1 & 2 \\
\hline 24 & 4 & 5 & 4 & 5 & 4 & 5 & 5 & 5 & 4 & 5 \\
\hline 25 & 4 & 4 & 4 & 4 & 4 & 4 & 4 & 4 & 4 & 5 \\
\hline 26 & 4 & 3 & 4 & 4 & 3 & 4 & 4 & 4 & 4 & 4 \\
\hline 27 & 2 & 2 & 1 & 1 & 2 & 1 & 1 & 5 & 1 & 1 \\
\hline 28 & 2 & 2 & 1 & 3 & 3 & 2 & 2 & 2 & 1 & 1 \\
\hline 29 & 2 & 2 & 1 & 3 & 2 & 2 & 2 & 2 & 1 & 1 \\
\hline 30 & 4 & 4 & 4 & 4 & 3 & 4 & 5 & 5 & 4 & 5 \\
\hline 31 & 4 & 3 & 4 & 2 & 3 & 3 & 3 & 3 & 4 & 5 \\
\hline 32 & 3 & 3 & 4 & 2 & 3 & 3 & 3 & 3 & 4 & 2 \\
\hline 33 & 4 & 3 & 4 & 2 & 4 & 2 & 2 & 2 & 4 & 4 \\
\hline 34 & 2 & 2 & 1 & 2 & 2 & 1 & 1 & 2 & 1 & 1 \\
\hline 35 & 4 & 4 & 4 & 4 & 4 & 5 & 4 & 5 & 5 & 5 \\
\hline 36 & 1 & 2 & 2 & 2 & 2 & 1 & 2 & 1 & 2 & 1 \\
\hline 37 & 4 & 5 & 5 & 2 & 4 & 5 & 5 & 4 & 5 & 5 \\
\hline 38 & 2 & 2 & 2 & 2 & 2 & 2 & 1 & 3 & 2 & 2 \\
\hline 39 & 2 & 1 & 1 & 2 & 2 & 1 & 2 & 1 & 1 & 1 \\
\hline 40 & 4 & 4 & 4 & 4 & 5 & 5 & 4 & 4 & 4 & 5 \\
\hline
\end{tabular}

Keterangan:

\begin{tabular}{|c|c|}
\hline & Nilai / Bobot \\
\hline Sangat Setuju & 5 \\
\hline Setuju & 4 \\
\hline Netral & 3 \\
\hline Tidak Setuju & 2 \\
\hline Sangat Tidak Setuju & 1 \\
\hline
\end{tabular}

\section{Analisis Permasalahan Pada Pabrik Sarinda Bakery}

Seperti yang diketahui sebelumnya bahwa pabrik sarinda bakery belum memberikan penamaan atau pemberian kode pada setiap susunan barang, sehingga pencarian barang masih berdasarkan letak barang atau susunan tanggal expired pada barang yang disusun 
Karena belum adanya metode penyimpana yang diterapkan di dalam ruang produksi, pencarian lokasi barang ini dilakukan dengan melihat tanggal expired dari tumpukan barang tersebut, karena barang disusun berdasarkan tanggal expired yang sama. Permasalahan lain yang ditemukan pada ruang produksi ini adalah barang-barang dan peralatan tidak digunakan masih berada dalam ruang produksi. Selain itu, peralatan ditempat produksi masih belum dipisahkan menurut fungsinya, dan belum menggunakan pelat di ruang produksi. Dimana penyusunan tersebut masih kurang teratur dan masih ditemukan tumpukan kardus yang tidak sesuai tempatnya.

\section{Perancangan Penerapan Budaya 5S Pada Pabrik Sarinda Bakery}

1. Seiri (Sort/Ringkas/Pemilahan)

Seiri merupakan aktivitas yang bertujuan untuk memisahkan peralatan atau material yang tidak diperlukan dengan peralatan atau material yang masih diperlukan. Sehingga akan memberikan space yang lebih besar untuk menyimpan material lain yang masih digunakan. Pada tahapan ini pada ruang produksi belum terlaksana dengan baik, karena masih ada di beberapa sudut bagian dari ruang produksi yang terdapat tumpukan barang atau material yang tidak digunakan dan seharusnya dapat di letakkan pada bagian luar ruang produksi.

2. Seiton (Set In Order/Rapi/Penataan)

Seiton merupakan aktivitas yang bertujuan agar barang tersusun dengan rapi, sehingga mudah ditemukan atau digunakan. Dengan tersusunnya barang secara rapi akan meminimasi waktu yang dibutuhkan untuk mencari barang. Sehingga saat barang hendak diambil oleh user dapat ditemukan dengan cepat. Aplikasi langkah ini pada ruang produksi belum terlaksana dengan baik. Hal ini dapat dilihat dengan masih bertumpuknya material di lantai dan belum di tata berdasarkan kegunaannya. Belum pula adanya penataan tempat untuk jalannya manusia dan material handling, tidak adanya pembatas antara manusia dengan material handling. Sehingga jika ada pengunjung yang lewat, maka material handling harus berhenti sejenak, hal tersebut akan menyebakan penundaan waktu dalam pemindahan barang. Pada ruang produksi inipun juga belum adanya penamaan barang dan penamaan tempat pada setiap penyimpanannya. Pada ruang produksi peletakkan barang-barang masih belum tertata rapi karena masih ada jenis barang yang berbeda namun diletakkan di area yang sama dan berdekatan, atau dengan kata lain masih ada barang yang peletakkannya tercampur, baik itu barang jadi ataupun bahan baku. Penumpukan bahan baku ini juga akan menjadikan pekerja sulit dalam pengambilan bahan baku, karena tidak adanya jalan kecil agar perkeja bisa masuk dalam pengambilan bahan baku. Selain itu pada suatu tumpukan kardus baru yang nantinya akan digunakan untuk packaging produk jadi, tumpukan tersebut sangat tinggi dan berimpitan, akan sangat sulit dalam pengambilannya Sehingga tidak digunakannya pelabelan atau penamaan tempat, hal tersebut akan membuat pekerja memiliki waktu yang lama dalam pengambilan material bahan baku dan akan adanya kemungkinan terjadinya kesalahan penempatan bahan baku karena tidaknya penamaan atau pelabelan tempat/area, maka hal inipun juga akan berakibat pada proses produksi.

3. Seiso (Shine/Resik/Pembersihan)

Seiso merupakan aktivitas yang bertujuan untuk terjaganya kebersihan lingkungan kerja, baik tempat kerja maupun barang atau material yang terdapat di dalamnya. Aplikasi tahapan ini pada ruang produksi pabrik sarinda bakery sudah terlaksana dengan cukup baik. Hal ini terlihat dari tidak terdapat sampah yang berserakan di dalam ruang produski. Selain itu, setiap selesai proses produksi berjalan, para pekerja selalu memebrsihkan ruang produksi. Lingkungan yang bersih merupakan tanggung jawab dari keseluruhan karyawan.

Namun tumpukan sampah di luar gudang harus segera dibersihkan agar lingkungan luar gudang menjadi lebih bersih, atau jika perlu dicarikan tempat lain di luar lingkungan pabrik dan ruang produksi untuk membuang sampah tersebut, serta tumpukan barang-barang yang tidak diperlukan di dalamruang produksi, seperti tumpukan kardus bekas dan peralatan yang tidak digunakan lebih baik jika dibuang atau dipindahkan. Adapun tahapan-tahapan yang juga dapat dilakukan untuk mendukung atau mencapai seiso yang berkala adalah sebagai berikut:

- Menentukan daftar peralatan kebersihan yang dibutuhkan beserta jumlahnya

- Menentukan tanggung jawab kebersihan untuk setiap area

4. Seiketsu (Standardize/Rawat/Pemantapan)

Seiketsu merupakan aktivitas yang memiliki tujuan yaitu kegiatan pemilahan, penataan, dan pembersihan yang telah dilakukan tetap terlaksana secara berkesinambungan. Salah satu langkah yang diambil yaitu dengan membuat peraturan untuk kegiatan-kegiatan di dalam ruang produksi. Pada ruang produksi pabrik sarinda bakery, sudah membuat peraturan ataupun metode yang digunakan secara konstan atau berkesinambungan dalam pelaksanaan aktivitas di ruang produksi, hanya saja ada beberapa 
yang belum sehingga menyebabkan karyawan terkadang menunda pekerjaan selama proses produksi berlangsung. Usulan yang diberikan pada proses ini yaitu: Menerapkan reward dan punishment untuk mempertahankan kondisi yang bersih dan rapi. Reward merupakan pemberian penghargaan kepada karyawan yang mematuhi peraturan-peraturan dan berpartisipasi aktif dalam penerapan $5 \mathrm{~S}$. Reward yang diberikan bisa berupa piagam penghargaan atau plakat penghargaan atau bonus bagi para pekerja. Punishment diberikan kepada karyawan yang tidak mematuhi peraturan yang ada di dalam pabrik. Punishment dapat berupa denda dalam jumlah tertentu atau potongan gaji.

5. Shitsuke (Sustain/Rajin/Pembiasan)

Shitsuke bertujuan untuk membiasakan budaya $5 \mathrm{~S}$ sebagai upaya untuk menciptakan lingkungan kerja yang lebih baik. Salah satu langkahnya yaitu dengan memberikan pelatihan mengenai budaya $5 \mathrm{~S}$ dikalangan karyawan dan audit secara berkala. Pabrik sarinda bakery ini belum dilaksanakannya pelatihan 5S dan sosialisasi kepada karyawan bahkan hampir seluruh karyawan belum memahami atau bahkan mengetahui mengenai metode $5 \mathrm{~S}$.

\section{Uji Validitas}

Data Hasil Uji Validitas Hasil Kuesioner Implementasi 5S Dengan Menggunakan SPSS

\begin{tabular}{|l|r|r|r|r|r|}
\hline \multicolumn{2}{|c|}{. } & \multicolumn{2}{|c|}{ Item-Total Statistics } \\
\hline & $\begin{array}{l}\text { Scale Mean if } \\
\text { Item Deleted }\end{array}$ & $\begin{array}{r}\text { Scale Variance } \\
\text { if Item Deleted }\end{array}$ & $\begin{array}{c}\text { Corrected Item- } \\
\text { Total } \\
\text { Correlation }\end{array}$ & $\begin{array}{c}\text { Squared } \\
\text { Multiple } \\
\text { Correlation }\end{array}$ & $\begin{array}{c}\text { Cronbach's } \\
\text { Alpha if Item } \\
\text { Deleted }\end{array}$ \\
\hline P1 & 26.1500 & 117.669 & .849 & .866 & .957 \\
P2 & 25.8000 & 114.215 & .860 & .846 & .955 \\
P3 & 26.2750 & 108.204 & .891 & .979 & .954 \\
P4 & 25.9250 & 115.866 & .725 & .685 & .960 \\
P5 & 25.6000 & 120.246 & .747 & .701 & .960 \\
P6 & 25.8750 & 111.856 & .827 & .790 & .956 \\
P7 & 26.1250 & 106.369 & .878 & .838 & .954 \\
P8 & 25.9000 & 115.374 & .725 & .648 & .960 \\
P9 & 26.2000 & 106.164 & .900 & .979 \\
P10 & 26.0250 & 105.563 & .908 & .992 & .953 \\
\hline
\end{tabular}

Berdasarkan hasil output di atas, dapat disimpulkan indikator-indikator pertanyaan variabel implementasi 5S memiliki rhitung lebih besar dari nilai rtabel sehingga dinyatakan Valid.

\section{Uji Realibilitas}

Data Hasil Uji Realibilitas Hasil Kuesioner Implementasi 5S Dengan SPSS

\begin{tabular}{|c|c|c|}
\hline \multicolumn{3}{|c|}{ Reliability Statistics } \\
\hline Cronbach's & $\begin{array}{c}\text { Cronbach's } \\
\text { Alpha }\end{array}$ & N of Items \\
& $\begin{array}{c}\text { Standardized } \\
\text { Items }\end{array}$ & \\
\hline & .962 & 10 \\
\hline
\end{tabular}

Pengukuran yang reliabel akan menunjukan instrumen yang dapat menghasilkan data yang di percaya. Reliabilitas suatu konstruk variabel dikatakan baik jika memiliki nilai Cronbach's Alpha > 0,908. Maka berdasarkan hasil output diatas dapat dilihat bahwa Cronbach's Alpha 0,961 > 0,908. Hal ini berarti bahwa jawaban responden untuk variabel implementasi 5S sudah Reliabel. 


\section{Uji Korelasi}

Data Hasil Uji Korelasi Implementasu 5S Dengan Menggunakan SPSS

\begin{tabular}{|ll|r|r|}
\hline \multicolumn{2}{|c|}{ Correlations } \\
\hline & & $\begin{array}{r}\text { LingkunganKerj } \\
\text { a }\end{array}$ & $\begin{array}{r}\text { ProduktivitasKe } \\
\text { rja }\end{array}$ \\
\hline & Pearson Correlation & 1 & -471 \\
LingkunganKerja & Sig. (1-tailed) & 15 & .038 \\
& $\mathrm{~N}$ & $-471^{*}$ & 15 \\
& Pearson Correlation & .038 & 1 \\
ProduktivitasKerja & Sig. (1-tailed) & 15 & 15 \\
& $\mathrm{~N}$ & & 15 \\
\end{tabular}

Dari pengujian dan pengolahan data yang telah diuji, maka dapat disimpulkan bahwa pengujian yang telah dilakukan memiliki korelasi yang signifikan. Analisis korelasi atau asosiasi merupakan suatu studi pembahasan tentang derajad keeratan hubungan antar variable yag dinyatakan dengan koefisien korelasi. Hubungan antara variable bebas (X) dan variable terikat (Y) dapat bersifat :

- $\quad$ Positif, artinya jika variable bebas (X) naik, maka variable terikat (Y) naik

- $\quad$ Negatif, artinya jika variable bebas (X) turun, maka variable terikat (Y) turun

Berdasarkan nilai signifikasi : dari output diatas diketahui antara lingkungan kerja dengan produktivitas karyawan memiliki nilai signifikasi $0,038<0,05$ yang berarti terdapat korelasi yang signifikan. Selanjutnya, dari output diatas, diketahui bahwa nilai pearson correlation yang dihubungkan antara masing-masing variable mempunyai tanda bintang, ini berarti dapat disimpulkan bahwa dari tabel diatas terdapat korelasi yag signifikan antara variable satu dengan variable yang lainnya

\section{KESIMPULAN}

Berdasarkan hasil implementasi 5S didapatkan penilaian yang cukup baik dalam tempat produksi di pabrik Sarinda yang dapat dilihat pada hasil foto-foto dan hasil pengujian statistik yang telah dilakukan pada pabrik sarinda, sehingga dapat di simpulkan bahwa :

1. Metode 5S akan memberikan dampak yang positif terhadap kondisi pabrik dengan menerapkan Metode $5 \mathrm{~S}$ tempat produksi lebih nyaman, bersih dan setiap peralatan mudah didapat karena diletakan sesuai tempat dan fungsinya.

2. Penerapan metode $5 \mathrm{~S}$ pada ruang produksi pabrik sarinda belum terlaksana secara sempurna. Karena masih banyaknya barang yang belum tertata dengan baik, dan ada barang yang masih tertumpuk di dalam ruang produksi padahal tidak digunakan. Untuk kebersihan, pada bagian dalam ruang produksi sudah bersih.

3. Usulan perbaikan yang diberikan agar penerapan $5 \mathrm{~S}$ lebih optimal yaitu pada tahapan seiri (sort/ringkas), seiton (set in order/rapi), seiso (shine/resik), seiketsu (standardize/rawat), dan tahapan shitsuke (sustain/rajin). Pada tahapan seiri usulan yang diberikan yaitu barang-barang yang tidak digunakan harus segera dipindahkan atau dibuang ke tempat sampah. Pada tahapan seiton usulan yang diberikan yaitu perlunya penataan material di ruang produksi dan pemberian nama pada rak agar memudahkan pencarian barang. Pada tahapan seiso usulan yang diberikan yaitu tetap menjaga kebersihan dalam ruang produksi. Pada tahapan seiketsu diperlukan adanya peraturan agar lingkungan yang rapi dan bersih dapat dipertahankan. Kemudian untuk tahapan shitsuke diperlukan adanya audit dan sosialiasi berkaitan dengan budaya 5S agar karyawan di pabrik sarindasehingga dapat memahami nilai-nilai $5 \mathrm{~S}$.

\section{DAFTAR PUSTAKA}

Devani, V. (2016). Analisis Penerapan Konsep 5S di Bagian Proses Maintenance PT. Traktor Nusantara. Jurnal Teknik Industri: Jurnal Hasil Penelitian dan Karya Ilmiah dalam Bidang Teknik Industri, 2(2), 113-120.

http://manajemenproduksi.com/apa-itu-5s-dan-cara-penerapan- metode-5s/ (Online Acsess, 27 Oktober 2017)Handayani, 2005. Kaizen Culture, Education And Training, New York : Irwing Profesional

Haryadi Sarjono dan Wenda Julianita, spss vs lisrel : Sebuah Pengantar Aplikasi Untuk Riset, Jakarta : salemba empat, 2011

Hirano, Hiroyuki. (1996)., Penerapan 5S di Tempat Kerja: Pendekatan Langkah-langkah 
Praktis(terjemahan). Jakarta: PQM Consultants.

http://id.shvoong.com/business-management/management/2058338-sikap-danbudaya-kerja5s/\#ixzz2S0irb6U0 (Online Acsess, 19 Juli 2017)

http://Tariecliple.Wordpress.Com/2012/11/06/Teori-Super-5-Kaizen/ (Online Acsess, 28 Oktober 2017)Metode 5S.

Osada, T. (2004)., Sikap Kerja 5S: Seiri Pemilahan, Seiton Penataan, Seiso Pembersihan, Seiketsu Pemantapan, Shitsuke Pembiasaan. Penerjemah: Dra. Mariani Gandamihardja. Jakarta. Penerbit PPM.

Rinawati, D. I., WP, S. N., \& Lisano, N. (2016). Rancangan Penerapan 5S Guna Mereduksi Searching Time Pada Area 1 PT. XYZ. Prosiding SNST Fakultas Teknik, 1(1).

Tatang M. Amirin., (2010)., Skala Likert : Penggunaannya dan Analisis Datanya., Jakarta

Wiratmani, E. (2015). Implementasi Metode 5 S Pada Divisi Gudang Barang Jadi (Studi Kasus Pada PT. $X)$. Faktor Exacta, Vol. 3 No. 3, pp. 268-286.

Yunita, S. (2007). Perancangan dan implementasi 5S di biro X universitas Y, Doctoral dissertation, Petra Christian University. 